\title{
Perception of Tertiary Institution Students Towards Mobile Assisted e- Cheating and Nigerian Examination Quality: Focus on Lagos State Tertiary Institutions.
}

\author{
Oyeyemi S.O.E.A. Adeyemo* \\ School of Education, Adeniran Ogunsanya College of Education, Lagos, Nigeria.
}

Mustapha Sulaimon Babatunde

Department of Social Studies Education, Adeniran Ogunsanya College of Education, Lagos, Nigeria.

Article history

Received:

13.04.2018

Received in revised form: 06.06 .2018

Accepted:

07.06.2018

Key words:

Examination malpractice, echeating, Digital cheating, Corruption, Gender

Involvement, Lagos State

Tertiary Institutions.
Students use mobile-phones to store lecture-materials, e-books, tutorials, videos, communicate with their classmates and browse the internet for exceedingly different intentions. These projectedadvantages, however, would have potential undesirable effects if mobile phones are utilised in restricted premises, such as examination venues. Noncompliant students (to general tertiary institutions exam regulations) do use mobile phones to cheat in examinations. Several studies have emerged on examination misconduct in Nigeria, but "e-cheating"e and its effects on quality of examination as a new form of examination fraud is yet to be given adequate attention in literature. This study is provoked to address this problem as regards Lagos State tertiary institutions. From four randomly selected tertiary institutions in Ojo Local Government Area of Lagos State, three hundred students were used as samples. The study examined students perception of mobile assisted echeating and gender involvement in e-cheating in examinations. Data were collected from the adopted instrument of Jones, Reid and Bartllet (2006) which has a Cronbach Alpha reliability score of 0.83 tagged "Perception toward examination e-cheating". Using a simple correlation and a student t-test to analyse the hypotheses, the study reported a significant relationship between dysfunctional effects of e-cheating on the quality of examination. It equally revealed a significant difference in e-cheating habit between male and female students. The paper also identified inadequate funding, corruption, issues bordering on morality and legality as challenges to curbing examination e-cheating in Lagos State tertiary institutions. The study recommended the involvement of all stakeholders in curbing this societal evil. 


\section{Introduction}

In Nigeria there has been a growing concern about the conduct, authenticity and quality of examinations especially during the process of selecting qualified prospective candidates into Nigerian tertiary institutions. The examinations enhance manpower production that promotes societal growth. The alarming rate of examination misconduct poses a threat to this objective. Digitally in recent times, another form of Information and Communication Technology (ICT) perpetuated examination mal-practices is on the increase. Ordinarily, students use mobile-phones to store lecture-materials, e-books, tutorials, videos, communicate with their classmates and browse the internet for exceedingly different intentions. These projected advantages, however, would have potential undesirable effects if mobile-phones are utilised in restricted premises, such as examination venues. Non-compliant students (to general tertiary institutions exam-regulations) do use mobile-phones to cheat in exams. The rapid explosion of cell phones at the beginning of the 21 st century eventually raised problems, such as their potential use to invade privacy or contribute to widespread academic-cheating (Okebukola, 2014).

The advancement and wide-usage of mobile devices facilitates learning media, increasing integration of mobile-phones into instruction in the institutions (Masri, 2015). In spite of the vital-role that is played by mobile phones as a learning tool, there still are challenges that could originate from using mobile devices, such as cheating during exams and distraction during lecture hours. Nyamawe and Mtonyole (2014), for example, observed that, recently institution authorities have noted an overwhelming increase in the use of mobile devices by students to cheat during examination tagged, e-cheating.

In Nigerian tertiary institutions, ICT has resulted in high level of examination misconduct, tagged "e-cheating" among students. "E-cheating" according to Omonijo (2011) is the habit of students engaging ICT devices to indulge in examination misconduct. The menace has now provided a smart way for notorious students to beat the effort of civil society groups and wellmeaning Nigerians in curtailing examination fraud (Omonijo et al., 2011). Prior too the invention of ICT, the menace of examination misconduct was a big problem to the nation's education system (Oduwaiye, 2005, Ijaiya, 2006, Joshua, 2008, Olatunbosun, 2009, Omonijo \& Fadugba 2011). Sadly, cheating with the aid of mobile devices has become one of the major negative fallouts of the use of technology in education. Electronic cheating or echeating may be viewed as the use of Information and Communication Technology to gain an undue advantage in an examination (Adeoye, 2010). This include, but not limited to the use of cell phones, programmable calculators, pagers, personal digital assistants (PDAs), computers, internet and so on to gain unfair advantage. Technology was originally meant to enhance the education process and not to distort it (Reid \& Bartllet, 2006). The use of technological tools for examination malpractices does not make technology a culprit. It is only a case of good things finding themselves in the hands of bad users. Possible abuse should not be a reason to discredit such technologies. E-cheating has taken examination malpractices to a new dimension in Nigerian tertiary institutions.

As reported by Okebukola (2014), the manifestation of the analogue methodology of examination malpractice in Nigeria reached new heights around 2005. According to Okebukola, by 2006, the supremacy of the analogue started yielding to digital, driven in large part by the increase in the use of mobile devices by candidates. Forms of e-cheating: the following are the observed ways through which students carry out e-cheating:

a. Coded information is stored in handheld devices which are brought into the examination hall. 
b. Leaked question papers with answers are downloaded from dubious websites

c. Use of mobile devices in exchange of answers among candidates and touts (outside the halls) during examinations.

d. Copying of notes into ipads which are taken into examination centres.

e. Stuffing needed information in cell phones and taking such into the examination hall

f. Taking pictures of notes with cell phones and using same to gain unfair advantage during examinations

g. Voice recordings of notes for use during examinations

h. Taking a photo of question papers and sending same to someone outside the examination hall, with answers sent back as images or text messages.

i. Storage of needed notes and formula in programmable calculators for use during examinations.

j. Use of cell phones calculators in examination where calculators are not allowed.

$\mathrm{k}$. Use of handheld devices to browse for solutions during an examination.

Jekayinfa (2010) identified Computer as one of the prominent technologies being used by students to perpetuate examination misconduct in Nigeria. This involves the use of calculators, which have facilities for multiple entries. Most invigilators, especially those who are not ICT-compliant may not know that it has such facilities. They may think it is an ordinary calculator. More often than not, many students who inscribed answers on their calculators have been caught in examination halls copying verbatim what they put on their calculators into their answer scripts. In architecture, where computer is being used to write examinations, students have been caught sending answers to another student through internet. Directly connected to the above is web site link with examination misconduct. Harris and Schoenig (2010), view it as a tool of perpetuating examination misconduct. According to them, chat rooms and social networking sites have increased in popularity, the incidents of candidates violating confidentiality rules and exposing copyrighted test content have also increased. Lecturers who are ready to collaborate with students in order to cheat in examinations often reveal pretest items, questions and answers prior examination through web-chat rooms and social networking sites. Nweke (2009), described mobile devices as other vital instruments of carrying out examination fraud. He singled out mobile devices short message service as a means of perpetuating examination misconduct in Nigerian higher institutions. Nweke, (2009) asserted that the fraud has continued to rise among Nigerian students. Buttressing the above view, Akesuola (2009) claims that some students used to store answers on their phones and bring them to the examination hall in order to copy them on their script while Assam, (2009) reveals a worrisome dimension of this act by asserting that some female students actually hide their phones, which contain answers to questions being examined in their under-wears and when confronted by the invigilators, they claim were only adjusting their sanitary towels to make it firm.

The problem is becoming aggravated and unbearable because many examination officials, including University staff, collaborate, connive and collude with students to perpetuate the dysfunctional habit, when students might have bribed them (Olatunbosun, 2009). To worsen the situation, the Nigerian judiciary has never brought any culprit to book (Omonijo \& Fadugba, 2011). Infact, members of the judicuary, parents, teachers and government functionaries were indicted in the act (Omonijo \& Fadugba, 2011). Consequently, several cases of "e-cheating" were not reported by many examination officials, while most of the few ones reported were poorly prosecuted, due to corruption (Nweke, 2009). This brings to the fore most of the reasons why government has failed to provide adequate solutions to the menace. The government itself constitutes a big problem to the remedy because most officials 
got to office through cheating, that is, rigging elections, bribery, forging of certificates and other manipulations. Hence, they lack moral justification and good conscience to wage war against the habit. As a matter of fact, Nigerian system does not reward integrity, hardwork, effectiveness and efficiency. Instead, disorderly behaviour and bad conducts are often interpreted as traits of smartness and bravery (Balogun et al, 2012).

Thus, liars, treasury looters, smugglers and murderers are applauded and embraced in villages, town and cities across the nation (Omonijo \& Fadugba, 2011). In-spite of the above, however, studies on "e-cheating" habit among students in Nigerian tertiary institutions are yet to be given adequate attention in literature. The recent study of Adebayo (2011), conspicuously omitted the social problem. Although, Adeoye, (2010) attempted to address the issue in his "Emerging Communication Technology and Examination Malpractices in Nigeria Educational Sector" but no attempt was made to establish if a significant difference exists in "e-cheating" habit between ICT-compliant students and other students in programs not science-oriented. Moreover, the study did not determine whether a significant difference exists in "e-cheating" habit between male and female students. Moreso, the need to carry out such study in ICT sophisticated cosmopolitan cities using mobile assisted approach and how availability of network frequency aids e-cheating is necessary. Thus, the need to make up for these gaps in knowledge in area of education in Nigeria makes the current study very pertinent. Its findings would further reveal various methods as well as types of ICT tools that students employ in perpetuating examination fraud in Nigerian Universities. The problem of "e-cheating" if not properly handled will keep on undermining the quality of our examinations and graduates ${ }^{\text {ee }}$ performances in work settings. The contributions to education to national development as well as the integrity of Nigerians in international community may be questionable.

\section{Theoretical Framework}

This study is theoretically framed on Functionalism; it provides a sociological platform for analyzing "e-cheating" habit of students, an aspect of crime in tertiary institutions in Nigeria. Going by the paradigm, crime is regarded as a part of social life that is functional to the societal well-being (Durkheim, (1982) cited by Omonijo, (2008) by providing a means of livelihood for a section of the society. Staff of institutions created to checkmate crime in the society members of the judiciary, Economic and Financial Crime Commission (EFCC), police, State Security Agents (SSA) are in this category. Giddens (2001), in this study, anti-social behavior, internet conflict and e-cheating are seen as what hinder educational and societal progress, most especially with youths that are internet natives and emerging technological changes and advances in the $21^{\text {st }}$ century. Marxian scholars condemn and dismiss functionalist point of view and argue that crime is the end product of exploitation of the proletariats by the bourgeois in capitalist societies. In other words, cheating does not just erupt because there are specific functions attached to it, it is a reaction to the exploitation of the masses by the ruling class.

Elites who perform state activities, use the general powers of the state to pursue their own particular interests within the state hierarchy (Marx, 1975). Although this view undermines prevalence of crimes in socialist societies, but it rings a bell in the capitalist societies of many underdeveloped countries. In Nigeria, it brings to bear or confirm bad management of the country by the elites in power as well as the looting of resources meant for national development to their own advantage; and to the detriment of common man (Omonijo, 2008). The adverse effects of these are traceable to the current high level of lawlessness and poverty 
prevailing across the nation and it could play a cogent role in the escalation of cheating among the citizenry. However, the Nigerian value system seems to aid examination malpractices, the structure of Nigeria makes law for the prosecution of students who indulge in examination misconduct, but the same system has never prosecuted any offender.

The study of Omonijo and Fadugba, (2011) on "Parental Influence of Wards in the Escalation of Examination Misconduct in Nigeria" attributes the failure to prosecute violators of examination misconduct to the fact that most children of government functionaries are involved. The structure also stretches out merit system as one of the criteria for job placement in work settings, but the same system is largely encouraging favouritism, quota system and federal character, which counters meritocracy in recruiting people to public service. In most cases, the rule of the game is "who you know". It does not matter whether one is qualified or not, so long as the candidate has a certificate and he or she is highly connected. In addition, the structure of Nigeria as a nation makes provision for people to be educated but the same system fails to make employment opportunities available for these people to earn a living and cater for their families. By and large, crime could provide a means of survival to a section of the public, resulting in temporary relief from poverty for this class of people. The sociological relevance of the relief is very crucial to the continuity of the entire society; as it preserves the section from starvation and extinction. Nevertheless, a section that is benefiting from crime cannot be compared with the majority that bears its cumulative effect in the long run. The more crime escalates in a society, the more it contaminates the whole nation and makes her backward in the community of nations.

\section{Purpose of the study}

The objective this study sets to achieve include to:

- Ascertain the perception of Lagos State Tertiary Institutions students towards the use of mobile assisted devices in e-cheating as regards the quality of examination

- Examine the extent to which Male students manifest significantly in e-cheating habit than female students

\section{Research Questions}

The following research questions were answered in this study:

- What is the perception of Lagos State Tertiary Institutions students towards the

- Use of mobile assisted devices in e-cheating as regards the quality of examination

- To what extent will Male students manifest significantly in e-cheating habit than female students

\section{Research Hypotheses}

The null hypotheses generated and tested on the research questions for this study are:

- There is no significant relationship between mobile assisted e-cheating and the quality of examination in Lagos State.

- There is no significant difference between Male student's involvements in mobile assisted e-cheating habit to female students. 


\section{Methodology}

Survey research was adopted in the study. The basis for the adoption is mainly because it involved sampling moderately large number of the respondents to gather information about a phenomenon. The sample population for the study consisted of students from Lagos higher institutions comprising Lagos State University Ojo, (LASU), Adeniran Ogunsanya, College of Education Otto/Ijanikin, (AOCOED), Lagos State Polytechnic (LASPOTECH) and Michael Otedola College of Primary Education, Epe (MOCPED). Using a purposive sampling based on versatility of students' internet usage, 75 students were selected from each of the institutions summing the total of 300 students. The table 1 below presents the distribution of the sample on the basis of gender and institutions.

Table 1. Distribution of sample on the basis of gender and Institutions

\begin{tabular}{llllll}
\hline & & & & & TOTAL \\
\hline Gender & LASU & AOCOED & MOCPED & LASPOTECH & \\
Male & 46 & 42 & 50 & 39 & 177 \\
Female & 29 & 33 & 25 & 36 & 123 \\
\hline Total & $\mathbf{7 5}$ & $\mathbf{7 5}$ & $\mathbf{7 5}$ & $\mathbf{7 5}$ & $\mathbf{3 0 0}$ \\
\hline
\end{tabular}

The instrument of study was adopted from Jones, Reid and Bartllet (2006) with modification according to the condition in Lagos State, Nigeria. The questionnaire was tagged "Questionnaire of Students Perception on e-cheating" (QSPE). Section A of the instrument requires the respondents to indicate their bio data such as gender, level of study and programme of study. Section B, of the instrument consist of twenty items referring to various method of e-cheating adopted in Lagos State tertiary institutions during examination. Respondents are required to tick either of the following options provided "Appropriate" and "Inappropriate" for items one to ten. In items eleven to twenty respondents are to tick either "Male" or Female gender in order to indicate their responses to each items provided in the instrument.

The instrument was validated using content validity approach, of which test and measurement expert in student internet usage mobile devices was given to ascertain the suitability of the instrument for the study. The instrument was also found reliable at a co-efficient of 0.83 that was obtained using Test- retest method. The data were analyzed using descriptive statistics (percentages) and differential statistics (T-test). The analysis was done using the student simple correlation and to determine the impact of e-cheating on the quality of examination and on the basis of gender in Lagos State, Nigeria.

\section{Results}

(a) What is the perception of Lagos State Tertiary Institutions students towards the use of mobile assisted device in e-cheating as regards the quality of examination

Table 2. Mobile Assisted e-Cheating and the Quality of Examination in Lagos State.

\begin{tabular}{|c|c|c|c|c|c|c|}
\hline $\mathbf{S} / \mathbf{N}$ & Items & Inappropriate & $\%$ & $\begin{array}{l}\text { Appropria } \\
\text { te }\end{array}$ & $\%$ & Total \\
\hline 1 & $\begin{array}{l}\text { Using unauthorized calculator in an } \\
\text { examination for } 111 \mathrm{e} \text {-cheating }\end{array}$ & 169 & 56 & 131 & 44 & 300 \\
\hline 2 & $\begin{array}{l}\text { Copying and pasting material from an } \\
\text { electronic devices for e-cheating in } \\
\text { examination }\end{array}$ & 152 & 51 & 148 & 49 & 300 \\
\hline
\end{tabular}


website to solve questions in examination

4 Coded information is stored in handheld

devices for e-cheating.

5 Use of mobile devices in exchange of

answers among students

Copying of notes into ipads

Stuffing needed information in cell

phones

Taking pictures of notes with cell phone

Hacking of examination questions

Using cell phones calculators in

examination where calculators are not allowed.

\begin{tabular}{lllll}
162 & 54 & 138 & 46 & 300 \\
159 & 53 & 141 & 47 & 300 \\
173 & 58 & 127 & 42 & 300 \\
153 & 51 & 147 & 49 & 3000 \\
164 & 55 & 136 & 45 & 300 \\
152 & 51 & 148 & 49 & 300 \\
161 & 54 & 139 & 46 & 300 \\
179 & 60 & 121 & 40 & 300 \\
& & & & \\
\hline $\mathbf{1 6 2 4}$ & $\mathbf{5 4}$ & $\mathbf{1 3 7 6}$ & & $\mathbf{4 6}$ \\
\hline
\end{tabular}

The data above on table 2 reveals the perception of students to e-cheating in relation to examination quality in Lagos State tertiary institutions. 54\% of the respondent perceived echeating as being inappropriate as regards improving the quality of examinations. While $46 \%$ perceived e-cheating as being appropriate for improvement of the quality of examination. This perception may be from students with studying habit problems that could not cope with the academic challenges of tertiary institutions.

\section{(b)To what extent will male students manifest significantly in e-cheating habit compared to female students}

Table 3. Showing Gender Involvement in Mobile Assisted e-cheating in Lagos State Tertiary

\begin{tabular}{|c|c|c|c|c|c|c|}
\hline \multicolumn{7}{|c|}{ Institutions } \\
\hline $\mathbf{S} / \mathbf{N}$ & Items & Male & $\%$ & Female & $\%$ & Total \\
\hline 1 & $\begin{array}{l}\text { Hacking school portal to gain access to } \\
\text { examination questions. }\end{array}$ & 152 & 51 & 148 & 49 & 300 \\
\hline 2 & $\begin{array}{l}\text { Handheld device storing of already prepared } \\
\text { answers and lecture notes for copying in the } \\
\text { examination hall. }\end{array}$ & 139 & 46 & 161 & 54 & 300 \\
\hline 3 & $\begin{array}{l}\text { Storing of already prepared answers and } \\
\text { lecture notes in Ipads in examination }\end{array}$ & 159 & 53 & 141 & 47 & 300 \\
\hline 4 & $\begin{array}{l}\text { Calculators inscribing of materials on the } \\
\text { cover of the calculator that are relevant to the } \\
\text { examination. }\end{array}$ & 171 & 57 & 129 & 53 & 300 \\
\hline 5 & $\begin{array}{l}\text { Use of handheld devices to browse for } \\
\text { solutions during an examination. }\end{array}$ & 148 & 49 & 152 & 51 & 300 \\
\hline 6 & $\begin{array}{l}\text { Mobile phones writing answers in form of } \\
\text { text messages, typing of lecture note on } \\
\text { phone }\end{array}$ & 162 & 54 & 138 & 47 & 3000 \\
\hline 7 & $\begin{array}{l}\text { Ipad Copying and sending of answers from } \\
\text { one student to another in a shared local } \\
\text { network }\end{array}$ & 142 & 47 & 158 & 53 & 300 \\
\hline 8 & $\begin{array}{l}\text { Taking a photo of question papers and } \\
\text { sending same to someone outside the } \\
\text { examination hall, with answers sent back as } \\
\text { images or text messages. }\end{array}$ & 163 & 54 & 137 & 46 & 300 \\
\hline 9 & $\begin{array}{l}\text { Voice recordings of notes for use during } \\
\text { examinations }\end{array}$ & 128 & 43 & 172 & 57 & 300 \\
\hline 10 & $\begin{array}{l}\text { Stuffing needed information in cell phones } \\
\text { and taking such into the examination hall }\end{array}$ & 166 & 55 & 134 & 45 & 300 \\
\hline & Total & 1530 & 51 & 1470 & 49 & \\
\hline
\end{tabular}

The data from table 3 reveals that $51 \%$ representing the male gender are more involved in echeating compared to the female gender that was represented with $49 \%$. This implies that the female gender e-cheating is on the increase since it's formerly postulated that male gender has 
higher tendency for anti-social behaviour than the female gender.

Table 4. Simple Correlation Table Showing Relationship Between Mobile-Assisted echeating and Quality of Examination in Lagos State Tertiary Institution

\begin{tabular}{lllllllll}
\hline Var. & N & X & SD & DF & S.G/L & r-cal & r-crit & Remark \\
\hline $\begin{array}{l}\text { Mobile Assisted e- } \\
\text { cheating }\end{array}$ & 300 & 5,413 & 2,384 & 598 & 0,05 & 0,697 & 0,4438 & Significant \\
$\begin{array}{l}\text { Quality } \\
\text { Examination }\end{array}$ & of & 300 & 4,587 & 2,170 & & & & \\
\hline
\end{tabular}

From table 4 above it shows that 300 students participated in the study, mobile assisted echeating have a significant high mean value of 5.413 and standard deviation of 2.384 while the quality of examination have a low mean value of 4.587 and 2.170 as its standard deviation. The correlation table for $r$ value was 0.697 significant at 0.05 . Hence the null hypothesis previously stated is rejected and alternative which states that there is a significant relationship between mobile assisted e-cheating and the quality of examination is therefore upheld.

\section{(c) There is no significant difference between male students' involvement in mobile assisted e-cheating habit to female students.}

Table 5: Student T-test Analysis Showing Difference Gender Involvement in mobile-Assisted

\begin{tabular}{lccccccc} 
& \multicolumn{7}{c}{ e-cheating. } \\
Variables & $\mathbf{N}$ & $\mathbf{X}$ & $\mathrm{SD}$ & $\mathbf{D F}$ & $\mathrm{S} . \mathrm{G} / \mathrm{L}$ & $\mathrm{t}$-cal & t-tab Decision \\
\hline Male Gender & 300 & 5.10 & 2.30 & & & & \\
& & & & 598 & 0.05 & 38.391 & 1.96 \\
$\begin{array}{l}\text { Rejected } \\
\text { Female Gender }\end{array}$ & 300 & 4.90 & 2.256 & & & & \\
\hline
\end{tabular}

Table 5 above it reveals that 300 participated in the study. Male gender had a higher mean value of 5.10 and standard deviation of 2.30 while female gender have low mean value of 4.90 and standard deviation of 2.256 respectively. The t-calculated value was 38.391 . While at 0.05 level of significant the t-table was 1.96, hence the null hypothesis is rejected while the alternative hypothesis which states that there is a significant difference of gender involvement in mobile assisted e-cheating practice

\section{Discussion}

Hypothesis one examined a significant relationship between e-cheating and quality of examination in Lagos State tertiary institutions. Hypothesis two equally investigated a significant difference in gender involvement in e-cheating habit between male and female students. The findings reported in this research point to the fact that adequate knowledge of ICT could result in its engagement to commit cheating which reduces the quality of examination. This that implies students in Lagos State tertiary institutions perceive the use of mobile devices as a short-cut to examination success. Most of these students might have gained admission into tertiary institutions through sorting themselves through "Special Centres". Coping with rigorous academic activities therefore becomes a problem. Moreover, table 3 goes to confirm the result of hypothesis two in respect of gender connotation of echeating. According to the table, male students were more involved in e-cheating than their female counterparts in examination. This corroborates Lombroso (1903) cited by (Omonijo et al., 2011), who concluded that female criminals are rare. Female folk according to him have 
not evolved like males, due to their inactive nature. In another development, Anugwom et al., (2010) conclude that male students undertake science programme more than their female counterparts. Hence, this could be the main reason while they are more involved in e-cheating habit than their female counterparts.

Hinman (2000) and Underwood (2006) proposed a three way approach to dealing with echeating in examination. The three approaches are:

- Virtues approach

- Prevention approach

- Policeman approach

The Virtues approach involves developing students who do not want to cheat as well as creating an environment that does not encourage cheating. This begins with institutions of learning formulating and making relevant policy statements on examination malpractices. It is not enough to formulate policies; the students must be convinced that the institution is committed to such policies. One way to show commitment is for the institution or school to ensure that all its dealings and practices are ethically carried out as dictated by relevant laws. The institution will lack the moral right to condemn cheating among students if it is involved in shady, sharp and shabby practices. Brown and Howell (2001) posited that institutional commitments to policy statements on examination malpractice can influence students' perceptions. The teachers and lecturers should also should lead exemplary lives. They should demonstrate commitment and forthrightness in their dealings with students. Underwood and Sarbo (2004) observed that levels of malpractice decrease when students perceive that their teachers are committed and forthright.

Prevention approach consists of digital and non- digital actions taken to reduce or out rightly prevent cheating before, during and after examinations. Some of such actions include, but not limited to the following:

(1) Ensuring the security of examination question papers and answer sheets before and after the examination.

(2) Producing multiple forms or versions of examination questions and ensuring that no two candidates having the same version of question papers are seated close to each other. This implies that the questions are same, but the numberings are different.

(3) Setting up of online multiple choice examination questions which present each candidate with questions randomly selected from the test bank; No two students are presented with identical questions.

(4) Disallowing students from bringing in mobile technological devices into examination venues.

(5) Installation of jammers in examination halls. Jammers are devices which prevent radio equipment from sending and receiving signals relevant to their function. This will prevent communication between candidates and persons outside the examination hall. It will also hinder internet browsing during examinations.

(6) Installation of detection devices that could indicate whether a mobile device is being operated within an examination hall.

(7) The policeman approach entails monitoring and enforcement of laws and regulation guiding an examination. Monitoring and enforcement involves proper invigilation, apprehending and appropriate sanctioning of defaulters. The sanctioning of defaulters will serve as deterrent to others. 


\section{Conclusion}

Experience has shown that examination malpractices have been the bane of Nigeria's education system as both parents and teachers assist students in the curb of this crime. This ugly state of affairs has continually robbed off on both the standard and outcome of education in the country leading to a widespread call for a total overhaul and sanitisation of the entire educational system. The implications of examination malpractice among students are frightening and devastating. Examination malpractice destroys the foundation and fabric of any educational system. It makes formal assessments unreliable, educational objectives unattainable and portends a bleak future for any society. The emergence of e-cheating has added to the challenges of conducting credible and reliable examinations. The way forward is a holistic approach involving all stakeholders, using technological and non-technological solutions. Based on the findings of this study, it can be concluded as follows: first, e-cheating perceived by lecturer and students are almost the same, although with different levels of perception. Second, not all e-cheating behaviour perceived by student will provide unfair advantage. It means the students not convinced that e-cheating will provide unfair behaviour. So, it is necessary for lecturers to give understanding about unfair benefit of e-cheating and constitute a policy to build examination norms. Students should be pressed to focus on graduation and shun anti-social behaviours manifested through e-cheating in examination.

\section{Recommendations}

Re-orientation and advice are two important factors which can be employed in changing bad habits. Moreover, spiritual transformation can be used to reinforce these two factors. It may destroy the spirit behind immorality. Based on this understanding and the pattern of differences shown by the findings of this research, it is, therefore, suggested that:

(a) Students should be banned from bringing ICT devices such as mobile phones, Ipads, and palmtops to the examination hall. Private Christian Mission Institutions like Covenant and Redeemer Universities have already taken that step. Possession of mobile phone is outlawed while on campus in Covenant University. Other institutions should follow suit.

(b) Calculators should be properly scrutinised before the commencement of any examination. Any calculators with inscriptions should be seized prior examination.

(c) In courses where computer is extremely important for examination, mostly science programme such as Architecture, students should be properly monitored to avoid copying and sending of answers from one person to another.

(d) Programme, mostly counselling and spiritual should be organised for students to keep them abreast of the danger inherent in cheating, to their lives and the entire nation at first instance. Anyone caught after that should be expelled from the University.

(e) Internet on desktop computers should be disconnected when students are about to use these systems to write examinations.

(f) Any examination officials including university staff caught aiding and abetting echeating should be punished with severance without benefits.

(g) Government and its relevant agencies should critically look into the issues of corruption within its border and ensure that those caught be seriously sanctioned without fear or favour.

(h) Tertiary institutions in conjunction with the relevant authorities should mount pressure on to allow the use of cell phone signal jammers in examination centres

(i) Examination supervisors and invigilators should be trained and equipped to deal with the e-cheating antics of candidates. 
(j) Female candidates must dress properly and be thoroughly searched by female invigilators, before and during examinations.

(k) Disobedient and unruly candidates must be severely punished so as to serve as deterrence to others.

(1) Officials should be well remunerated, so that they would not be tempted with monetary gifts and bribes from candidates and their parents.

\section{References}

Adebayo, S. O (2011). Common Cheating Behaviour among Nigerian University Students. World Journal of Education (1) 144-149.

Adeoye, O. S. (2010). Emerging Communication Technology and Examination Malpractices in Nigeria Educational Sector. World Journal of Education, 1(1) 114-149.

Ajayi, I and Ayodele, J (2002). History and development of education. Ado-Ekiti: Petoa.

Akeusola, O. (2009). Mobile Phone and examination malpractices: I T Realms on Line. http://www.itrealms.com.ng/2009/09/mobile-phones-and-exam-malpractices.html curled 29/08/11.

Anugwom, E. E; Omonijo, D. O. \& Fadugba O. A. (2010). A review of gender performance of graduating students in a private christian mission university in Nigeria between 2008 and 2010. International Journal of Gender Empowerment and Development, 10, $1 \& 2,44-54$

Balogun, J. (2012) Examination malpractices and the Nigerian society. The Jos Journal of Education, 4(1), 110 - 116.

Brown, V and Howell, M (2001). The Efficacy of Policy Statements on Plagiarism: Do they Change Students' Views. Research in Higher Education, 42, p103118

Durkheim, E. (1982). The Rules of the Sociological Method, (Edited by Steven Lukes; translated by W.D. Halls). New York: Free Press.

ECPAT. (2005). ECPAT International Roundtable Meeting on Violence Against Children in Cyberspace. Bangkok Thailand: June 12-13. Examination Malpractice Act (2012) 'Examination Malpractice: Meaning' Retrieved from http://ozelacademy.com/EJESV1N3_1.pdf_br

Giddens, A. (2001) Sociology. Cambridge: Polity Press.

Harris, D. J and Schoenig, R. R. W. (2010). Investigating Exam Misconduct: Best Practices Before, During, and After the Examination. The bar examiner, 79, 2

Hinman, L (2000) Approaches to Cheating and Plagiarism. (Retrieved from http://www.academicintegrity.org/values.asp )

Marx, K. (1975). "Critique of Hegel's Doctrine of State”, in Karl Marx: Early Writings, trans. Rodney Livingstone and gregor Benton. New York: Vintage

Nweke, R. (2009). Mobile Phone and Examination Malpractices. I T Realms on Line. http://www.itrealms.com.ng/2009/09/mobile-phones-and-exam-malpractices.html curled $29 / 08 / 11$

Nwanjoka, O. (2002). Final Workshop Report: Introduction of Information and Communication Technologies in Rural Areas. [Online]. Available at: (http:Nwww.ics.trieste.it/documents/hightech/telecom/activitiestwsdec2002/Final $\% 2$ OReport.)

Nyamawe, A. \& Mtonyole, N. (2014). "The Use of Mobile Phones in University Exams Cheating: Proposed Solution”, International Journal of Engineering Trends and echnology (IJETT), Volume 17, Number 1, Nov 2014. 
Oduwaiye, R. O. (2005). "Students"e Perception of Factors and Solutions to Examination Malpractices in Nigeria Universities: A case study of University of Ilorin". Ilorin Journal of Education, 8, 24. Globalization: Post-Neo dependency and Poverty in Africa. Enugu: 4th Dimension Publishing Company Limited

Okebukola, P. (2014) Contemporary Use of Mobile Devices for Cheating During Examinations. The Guardian, Friday, September 18, pp.59.

Okebukola, P. (2014). "Contemporary Use of Mobile Devices for Cheating During Examinations", [Online] Available: www.ijern.com, (June 10, 2016)

Olatunbosun, J. B. (2009). "Examination Malpractice in Secondary Schools in Nigeria: What Sustains it Examination Malpractice in Nigeria What sustains it?" European Journal of Educational Studies, (1), 3, 6-7

Omonijo, D. O. (2008). Patterns of Corruption in Power Holding Company of Nigeria (PHCN), Awka. An Unpublished M. Sc thesis, Department of Sociology / Anthropology, faculty of Social Sciences, Nnamdi Azikiwe University, Awka.

Omonijo D. O, Nndeum, O. A. U. \& Ezeokana, J. O. (2011). Understanding the Escalation of brain drain in Nigeria from Poor Leadership Point of View. Mediterranean Journal of Social Sciences, (2), 3, 434-453

Omonijo D. O., Nndeum, O. A. U \& Ezeokana, J. O. (2011). The relationship Between Youthful Lust and Violation of GSM Rule in a Private Christian Mission University, South-West Nigeria. World Journal of Social Sciences, 2, (3),487-520.

Omonijo, D. O. \& Fadugba, O. (2011). Parental Influence in Escalation of Examination Malpractices in Nigeria. European Journal of Social sciences, 19 (2), 297-307

Oyeyemi, S.O (2016), Efficacy of Nigerian Thumb Tribe, Mobile Explorative Tweak and Cheat Creation in Redefining Secondary School Students learning Habit in Lagos State. Unpublished P.HD Thesis Department of Educational Foundation and Counseling Psychology, Lagos State University, Ojo Lagos.

Reid and Bartllet (2006). Perception of Students Towards e-cheating in Malaysia. Business Quarterly Journal, 74(2) 141-150.

Underwood, J. (2006) Digital Technologies and Dishonesty in Examinations and Tests (Retrieved From http://dera.ioe.ac.uk/6987/1/qca-06_digital-technologies-dishonestyexams- tests-report.pdf

Underwood, J and Sarbo, A (2004) Academic Offences and E-learning: Individual Propensities in Cheating. British Journal of Educational Technology, 34, 467 - 478. 